\title{
Size-biased dispersal prior to breeding in a damselfly
}

\author{
Bradley R. Anholt* \\ Ecology Group, Department of Zoology, University of British Columbia, Vancouver, BC Canada, V6T 2A9
}

Received October 26, 1989 / Accepted January 29, 1990

Summary. Dispersal is notoriously difficult to measure, so its potential population consequences are often unknown. If dispersal is density-dependent, it can act in population regulation. Adult damselflies Enallagma boreale (Zygoptera: Coenagrionidae) raised as larvae under a range of competitive regimes were individually measured and marked. Individuals that survived to reproductive maturity were either recovered at the natal pond or had dispersed to nearby water bodies. Dispersing individuals were heavier at emergence than those returning to the natal pond to breed. Therefore, an increased probability of dispersal does not appear to be a response to poor conditions in this species.

Key words: Density-dependence - Dispersal - Enallagma - Odonata

The time between emergence and the onset of sexual activity is the most poorly known stage in the life-history of odonates (Corbet 1962, 1980). At emergence, gonadal tissue is not fully developed, the exoskeleton is soft, and colouration is more cryptic than at sexual maturity. The maiden flight of odonates is oriented away from the natal pond (Moore 1954; Pajunen 1962; Parr 1976; Corbet 1980), and may lead the animal to another body of water. Dispersal along streams has been recorded (Waage 1972; Garrisson 1978; Garrisson and Hafernik 1981), as well as between water bodies (Mitchell 1962; Koenig and Albano 1987; Van Buskirk 1986). Waage found that male Calopteryx maculata were more likely to move along the stream immediately prior to sexual maturity than were females. However, the rarity of recording dispersal has usually prevented examination of whether some animals are more likely to disperse than others. Often, it has been assumed that dispersal is either rare or random with respect to individual characteristics

* Present address and address for offprint requests: Department of Biology, University of Michigan, Ann Arbor, MI 48109, USA (eg. Fincke 1982; Banks and Thompson 1985). Crowley et al. (1987) have speculated that adult dispersal from crowded larval conditions is a possible density-dependent factor relevant to population regulation of damselflies.

Determining whether or not there is a bias in the likelihood of dispersal of certain phenotypes requires an initially marked population of known phenotype. In addition, the probability of detecting a relationship between the likelihood of dispersal and phenotype is correlated with the level of phenotypic variance present (Draper and Smith 1981). In this paper I present data from a population of adult Enallagma boreale Selys ( $\mathrm{Zy}$ goptera: Coenagrionidae) subjected to a wide range of larval competitive regimes and compare marked individuals returning to their natal pond with those found at adjacent water bodies.

\section{Methods}

This study was carried out in the University of British Columbia Research Forest, in the Coast Mountains $35 \mathrm{~km}$ east of Vancouver, Canada. the primary study site was Thesis Pond, a small $(15 \times$ $25 \mathrm{~m}$ ) oval bog pond in a wet clearing. The study site was bounded on two sides by second growth Douglas Fir and Western Hemlock forest through which dispersing animals could reach Katharine Lake, $0.2 \mathrm{~km}$ distant. A third side was bounded by a $10 \mathrm{~m}$ high slope topped by a logging road, across which dispersing animals could reach Shirley Lake, $0.1 \mathrm{~km}$ distant. The fourth side was a hummocky bog draining the pond. Blueberry (Vaccinium sp.), willow (Salix spp.) and alder (Alnus rubra) were the predominant shrubs. Occassional areas of open water, supporting oviposition sites (Nuphar variagatum) were potential dispersal sinks. Rose Lake was $0.6 \mathrm{~km}$ in this direction.

\section{Study animals}

Adults were collected from covered cages where larvae were raised at various levels of habitat complexity, food availability and larval density. Larvae raised at high density or low food levels emerged at significantly smaller sizes later in the season (Anholt in press). 
Newly emerged wild adults were also collected from the margins of the study pond and nearby Shirley Lake. All adults were returned to the laboratory in ventilated $1 \mathrm{~L}$ jars and held overnight while the exoskeleton hardened. The following morning, wing length and abdomen length were measured to $\pm 0.1 \mathrm{~mm}$ with Vernier calipers and body mass was measured on an analytical balance to $\pm 0.1 \mathrm{mg}$ while the animal was restrained in a glassine envelope. Each animal was then uniquely marked with a combination of four coloured paint dots (FaberCastell Uni-Paint Marker ${ }^{\circledR}$ ), two on the left forewing, one on the thorax and one on the abdomen. The combined mass of the marks was less than $0.2 \mathrm{mg}(0.5$ to $1.0 \%$ live weight). After being marked, the animals were returned to the pond where they were released in the vegetation surrounding the pond. Animals that showed any difficulty in flying were not released. A total of 1156 animals were released. Animals returning to the pond were identified by one of two observers equipped with binoculars who patrolled the study pond beginning in the morning as the first males arrived at the pond and continued until the evening when reproductive activity had ceased. Observers were present on all warm sunny days from the beginning of emergence in early June until the end of the breeding season in early September. Animals that were not resighted at the pond may have died or moved to another body of water. Neighbouring Shirley Lake or Katharine Lake were searched for dispersing animals, 30 to $60 \mathrm{~min}$ each working day by one observer. Rose Lake was searched for dispersing animals 6 times. Few dispersing animals were recovered from these nearby water bodies, and none from Rose Lake; most animals were recaptured at the pond.

Because sexually mature males spend more time at the pond than do females, incomplete surveys of the potential dispersal sites will bias the probability of recovery to favour males. Therefore, these data cannot be used to test whether one sex is more likely to disperse than the other (Koenig and Albano 1988).

Differences between animals that dispersed to other waterbodies and those recaptured at the natal pond were tested in a linear model with date of emergence and dispersal as predictor variables using the MGLH module of SYSTAT. Date of emergence must be accounted for in the model because size at emergence declines as the season progresses. Data were analyzed in two sets: males alone and all recaptures. When females were included sex was included as a predictor variable to account for any sexual dimorphism. So few dispersing females were recaptured that a separate analysis was not performed.

\section{Results}

Of the 66 animals recovered at sexual maturity, one female and eight males were found at nearby water bodies. In addition, a single immature female was recaptured at Katharine Lake the day after release. Dispersing males were $1.7 \mathrm{mg}(6.8 \%)$ heavier than non-dispersing males. The analysis of covariance showed this to be a significant difference $\left(\mathrm{F}_{(1,37)}=4.62 ; P<0.04 ;\right.$ Fig. 1$)$. Including females (which assumes that the probability of dispersal is related only to mass at emergence and not influenced by sex), the ten dispersing animals were on average $2.1 \mathrm{mg}(7.5 \%)$ heavier at emergence than animals recovered at the natal pond. The analysis of covariance is similar to when females are excluded $\left(\mathrm{F}_{(1,64)}=5.88 ; P<0.02\right)$. Including sex as a predictor in the model does not improve the fit $\left(\mathrm{r}^{2}\right.$ (without) $=0.258$ vs. $\mathrm{r}^{2}$ (with) $=0.259$ ), and sex is not a significant factor $\left(\mathrm{F}_{(1,63)}=0.06 ; P>0.80\right)$.

Similar analyses were carried out for wing length and abdomen length. However, there was no evidence for a difference between the wing-lengths $\left(\mathrm{F}_{(1,37)}=\right.$

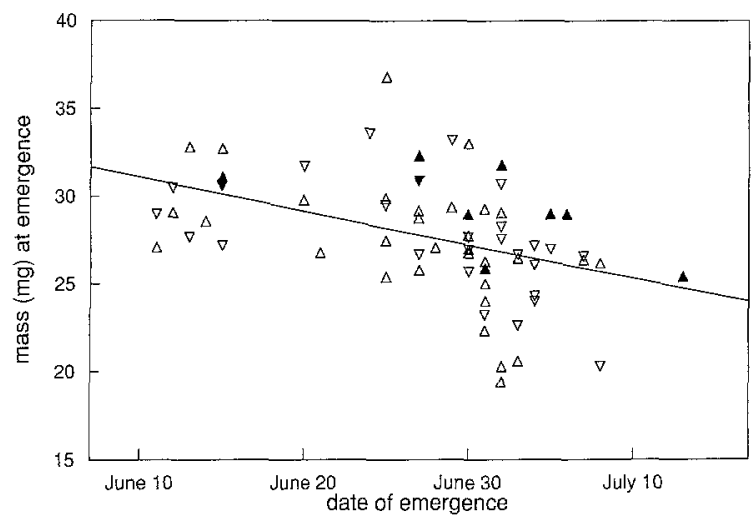

Fig. 1. Mass at emergence as a function of date of emergence of all resighted damselflies in 1985 . Open symbols (males $\triangle$; females $\nabla)$ are individuals recaptured at the natal pond and solid symbols were recaptured at a different water body

$0.32) ; P>0.57)$ or abdomen lengths $\left(\mathrm{F}_{(1,36)}=0.36 ; P>\right.$ $0.54)$ of dispersers and those animals that returned to breed at their natal pond. Including females in the analysis did not alter these conclusions. (wing: $F_{(1,63)}=0.00$; $P>0.98$, abdomen: $\left.\mathrm{F}_{(1,63)}=1.09 ; P>0.29\right)$.

\section{Discussion}

The propensity to disperse can have both genetic and environmental components (Dingle 1968). Increased likelihood of dispersal is usually associated with poorer environments rather than better ones; either because of slow growth (Topoff and Mirenda 1980), crowding (Tschinkel and van Belle 1976), or reduced mating opportunities (Lawrence 1988). For dispersal to be an effective agent of density-dependent population regulation in damselflies as proposed by Crowley et al. (1987), animals experiencing poor conditions must be more likely to disperse than those experiencing good conditions (Lomnicki 1978). This is clearly not the case here for $E$. boreale. Larger damselflies which are the result of better larval conditions (Anholt in press) were more likely to disperse to nearby bodies of water than were small ones.

Small damselflies may have dispersed further than large dispersing damselflies. If this was true, then the concentration of sampling effort nearby would be a biased sample of dispersing animals. However, the surveys of Rose Lake $(0.6 \mathrm{~km}$ distant $)$ did not recover any dispersing individuals.

One hypothesis to explain the larger size of dispersing animals is that large animals fly greater distances than small ones in their maiden flight immediately after emergence. Thus, they are more likely to encounter another body of water and not return to the natal pond when reaching sexual maturity. This hypothesis has not yet been tested.

Acknowledgements. The data in this paper were collected with the able and uncomplaining assistance of L. Waterhouse. The research was supported by a NSERC operating grant to W.E. Neill and PostGraduate Fellowship to myself. 


\section{References}

Anholt BR (1990) An experimental separation of interference and exploitative competition in a larval damselfly. Ecology (in press)

Banks MJ, Thompson DJ (1985) Lifetime mating success in the damselfly Coenagrion puella. Anim Behav 33:1175-1183

Caldwell RL, Hegman JP (1969) Heritability of flight duration in the milkweed bug Lygaeus kalmii. Nature 223:91-92

Corbet PS (1962) A biology of dragonflies. Witherby, London

Corbet PS (1980) Biology of Odonata. Annu Rev Entomol 25:189217

Crowley PH, Nisbet RM, Gurney WSC, Lawton JH (1987) Population regulation in animals with complex life histories: formulation and analysis of a damselfly model. Adv Ecol Res 17:1-59

Dingle H (1968) The influence of environment and heredity on flight activity in the milkweed bug Oncopeltus. J Exp Biol 48:175-184

Draper NL, Smith H (1981) Applied regression analysis (2nd ed.). John Wiley and Sons, New York

Fincke OM (1982) Lifetime mating success in a natural population of the damselfly Enallagma hageni (Walsh) (Odonata: Coenagrionidae). Behav Ecol Sociobiol 10:293-302

Garrisson RW (1978) A mark-recapture study of imaginal Enallagma cyathigerum (Charpentier) and Argia vivida Hagen (Zygoptera: Coenagrionidae). Odonatologica 7:223-236
Garrisson RW, Hafernik JE (1981) Population structure of the rare damselfly, Ischnura gemina (Odonata: Coenagrionidae). Oecologia 48:377-384

Harvey IF, Corbet PS (1985) Territorial behaviour of larvae enhances mating success of male dragonflies. Anim Behav 33:561-565

Koenig WD, Albano SS (1987) Breeding site fidelity in Plathemis lydia (Drury) (Anisoptera: Libellulidae). Odonatologica 16:249-259

Lawrence WS (1987) Dispersal: an alternative mating tactic conditional on sex ratio and body size. Behav Ecol Sociobiol 21:367373

Lomnicki A (1978) Individual differences between animals and the natural regulation of their numbers. J Anim Ecol 47:461475

Mitchell R (1962) Storm-induced dispersal in the damselfly Ischnura verticalis (Say). Am Midl Nat 68:199-202

Topoff H, Mirenda J (1980) Army ants on the move: relation between food supply and emigration frequency. Science 207:1099-1100

Tschinkell WR, Belle G van (1976) Dispersal of larvae of the tenebrionid beetle Zophobas rugipes, in relation to weight and crowding. Ecology 57:161-168

Waage J (1972) Longevity and mobility of adult Galopteryx maculata (Beauvois, 1805) (Zygoptera: Calopterygidae). Odonatologica $1: 155-162$ 